\title{
Babesa bilatzen duten pertsonen harreran inplikatutako jarrerak eta prozesu emozionalak: europar identitatea eta sentsibilizaziorako neurriak
}

\author{
Maitane Arnoso, Magdalena Bobowik, Janire Arroyo, Ainara Arnoso \\ eta Larraitz Zumeta \\ SOS Arrazakeria Gipuzkoa eta Gizarte Psikologia eta Portaera Zientzien \\ Metodologia Saila, Psikologia, UPV/EHU
}

\begin{abstract}
Babes-eskatzaileen eta immigranteen etorreraren aurrean hautemandako mehatxu eta beldurra Europako herrien sekurizazioarekin eta mugak ixten dituzten politika-neurrien hedapenarekin lotzen da. Artikulu honek aztergai ditu: fenomeno horren aurrean unibertsitateko ikasleek dituzten emozio eta jarrerak, identitate europarrak jokatzen duen papera, eta nola sentsibilizazio-ekintzen bidez bizilagun berriekiko balio prosozialak susta daitezkeen. Emaitzek adierazten dutenez, zenbat eta identifikazio europar altuagoa izan, orduan eta errefuxiatuei mugak ixteko neurriekin adostasun handiagoa azaltzen da. Aitzitik, zenbat eta europar identifikazio baxuagoa izan, orduan eta balio prosozial eta integrazio-neurriekin adostasun handiagoa. Sentsibilizazio-kanpainek errefuxiatuekiko emozio positiboak eta moralak gehiagotzen ditu eta elkartasunaren aldeko balioak zabaldu.
\end{abstract}

GAKO-HITZAK: Errefuxiatuak · Emozioak · Jarrerak · Europar identitatea . Sentsibilizazio-jarduerak.

\section{Attitudes and emotional processes involved in the reception of refugees: close of borders or integration?}

The threat and fear perceived by the arrival of migrants and asylum seekers and refugees, manage the extension of politics based on the securization of European cities and close of borders. This article explores the emotion and attitudes that students have in the face of this phenomenon, the role that plays European identity and how, using sensitivity actions is possible to promote prosocial values towards new neighbours. The results show that a high European identification is related to biggest agreement with close of borders. In reverse, a lower European identification is related with more prosocial values and agreement with integration measures. Sensitivity campaign manages to increase positive emotions and moral emotions toward refugees and extend solidarity values.

KEY WORDS: Refugees · Emotions · Attitudes · European identity · Awareness actions. 


\section{Sarrera}

Gaur egun Europak dituen hamaika erronketako bat atea jotzen duten ezezagun berrien aniztasun etnokulturalaren gizarteratzea da (Bauman, 2017). XXI. mendearen hasiera honetan, etxetik kanpo bizitzea gorantz doan mugimendua bihurtzen ari da. Datuak diotenez, mundu osoaren populazioaren $\% 3$ inguru bere jaioterritik kanpo bizi da (Murray eta Marx, 2013). 2015ean 65,3 milioi pertsona haien jaioterritik kanpo joatera behartuak izan ziren eta, horien artean, 21,3 milioi errefuxiatu zeuden mundu guztian zehar (UNHCR, 2016). Zifra hauek inoiz baino altuagoak dira eta, gainera, igotzen jarraitzea espero da (CEAR, 2016). Bestalde, milaka lagunek galdu dute bizia Mediterraneoko itsas bideetan, Europako kostaldera heltzeko ahaleginean.

Europak 2016an pertsona errefuxiatuak jasotzeko eta artatzeko hartutako konpromisoa ez da bete, eta Bigarren Mundu Gerran bizitako giza ezbeharraren pareko dramaren aurrean gaudela erakusten dute datuek. Europako Batzordeak 2017ko martxoan onartu zuen hasiera batean jaso behar zituen 160.000 lagunen \% 25 artatuko zituela azkenean (CEAR, 2017). Era berean, Europar Batasunak Schengen guneko (pertsonen mugikortasun askeko eremua) mugetako kontrolak zorroztean jarri du indarra. Horrek areagotu egin ditu berehalako itzultzeak, mugen esternalizazio-prozesuak eta hirugarren herrialde batzuekin egindako itunak. Herrialde horietako batzuk, gainera, giza eskubideen babeserako konpromiso lausoa dute; horren adibide da Europar Batasunak eta Turkiak sinatutako akordioa. Besteak beste, harrerarako eskubidea urratzea ekarri du itun horrek.

Babesa eskatzen duten pertsonen etorrera, estereotipoen, aurreiritzien eta emozioen testuinguru batean gertatzen dira, eta emozio horiek, egoera honen aurrean erabakitzen diren politikak eta jarrerak (babesaren aldekoak edo ukatzearen aldekoak) justifikatu eta bideratzen dituzte (Skitka et al., 2006). Talde arteko testuinguruetan emozioen ikerketa beharrezkoa da (Porat, Halperin eta Tamir, 2016), emozioek paper garrantzitsua jokatzen dutelako gizartearen erregulazioan. Horien funtzioa, klima emozional, atmosfera eta kultura emozional batetik, erlazio eta pertsonen arteko elkarrekintzetan uler daiteke (De Rivera, 1992; Conejero et al., 2004). Estereotipoak kolektibo estigmatizatuekiko portaeren kausa izan daitezkeela nabarmentzen dute zenbait autorek (Biernat eta Dovidio, 2000). Cuddy, Fiske eta Glick-ek (2007), aldiz, emozioak exotaldeekiko jarreren estereotipoak baino iragarle hobeak direla adierazi zuten, estereotipo-portaera loturaren artean bitartekari modura aritzen direlako. Nolanahi ere, jokabidezko aldagaietan edo zenbait neurri politiko zehatzetan eragina duten estereotipo eta emozioen artean erlazio egonkor bat existitzen dela dakigu. Orokorrean, babesa bilatzen duten pertsonen eta pertsona immigranteen deshumanizazioak emozio desberdinak sortzen ditu. Alde batetik, estatus baxuko eta ez hain mehatxagarri bezala hautematen ditugun taldeek tristura eta gupida emozioen artean ibiltzen diren emozioak sortzen dituzte. Beste aldetik, oraindik, gorrotoaren eta mespretxuaren artean dauden emozioak sentitzen ditugu estatus baxuagoa duten eta gure segurtasunerako mehatxagarri bezala hautematen ditugun taldeen aurrean. Taldeen arteko emozio positiboen adierazpena bakarrik izaten da posible konpetentzia baxuko edo talde arteko mehatxua dagoen testuinguruetan (Fiske et al., 2002; Cuddy, Fiske eta Glick-ek, 2008). Mehatxu hori 
sarri zenbait prozesu politiko eta mediatikoren bidez izaten da posible. Izan ere, mehatxu eta beldurraren diskurtsoaren ondorioz, posible izaten da giza eskubideak urratzen dituzten neurriak hartu eta zalantzakortasunik gabe onartzea. Hedabideen diskurtsoek eta diskurtso politikoek lagundu dute neurri horiek Europako hiritarren artean normaltasunez jasotzea. Kolektibo migratzailearen inguruan jendeak dituen estereotipo eta jarrera ezkorrak, oro har, bi mehatxu motarengatik izaten dira: mehatxu errealista (realisticthreat) eta mehatxu sinbolikoa (symbolic threat) (Stephan et al., 1998). Lehenengoa, bertako taldearen ongizatearekin eta errekurtsoekin (lanbideak, osasuna, boterea, etab.) erlazionatzen da. Bigarrena, berriz, ikuspegi moralaren mehatxua sentitzean datza (balioak, arauak, jarrerak. etab). Hau da, bertakoak beldur izaten dira babesleku bila datozen pertsonek ez ote dizkieten kendu, gutxitu edo aldatuko orain arte lortu dituzten gauza horiek guztiak (Louis et al., 2007). Bi mehatxu mota horiek herstura-maila igo egiten dute eta, horrela, diskriminazio-jarrerak handitu egiten dituzte (Stephan et al., 1998). Errefuxiatuengandik mehatxu sinbolikoa sentitzen duten pertsonek errefuxiatuekiko jarrera negatiboa edukitzeko joera dute, eta mehatxu errealista nabaritzen dutenek, aldiz, errefuxiatuekiko aurreiritzidun jarrera izateko joera dute (Schweitzer et al., 2005). Azken urteetan besteekiko gutxiespena Europan zabaldutako musulmanen aurkako sentimenduan zentratu da (Meer eta Modood, 2009; Strabac eta Listhaug, 2008). Sentimendu hori eraiki da Mendebaldean finkatutako balio demokratikoen, adierazpen-askatasunaren, genero-ekitatearen, laizismoaren edo tolerantziaren aurrean Islamaren mehatxuaren gainean (Kundnani, 2007; Bilsky, 2009; Saroglou et al., 2009; Elchardus eta Spruyt, 2014).

Gainera, gaur egun, sinboliko edo errealak izan daitezkeen beldur eta mehatxu ohikoez gain, europar gizarteak (eta bestek ere) bizi duen mehatxu terrorista ere kontuan hartu behar dugu. Hori, errefuxiatuen etorrerarekin lotu izan da diskurtso mediatiko eta politikoetan. Horren adibide argia da, besteak beste, Alemanian Angela Merkelek adierazitakoa, zeinak, Europan mugak irekitzearen ondorioz, errefuxiatuen fluxu bat gertatu eta terroristen kontrabando bat egon zela adierazi zuen (Saavedra, 2016). Espainiako politikarien artean ere, Percival Manglano Partidu Popularreko aurreko ekonomia-sailburuaren tweet-a gogora dezakegu, non Berlineko atentatu terroristaren egilea errefuxiatu pakistandar bat izan zela idazten zuen (González, 2016). Munilla apezpikuak ere sare sozialetan egindako zorigaiztoko iruzkina dugu, zeinak, Antonio Cañizares Valentziako artzapezpikuari elkartasun-adierazpenak bidali zizkion errefuxiatuak terroristak izan zitezkeela ohartaraziz (Alonso, 2015).

Jakin badakigu beldurraren diskurtsoek eragin handia izan dutela estatu eta eskualdeen segurtasun-politiketan (Altheide, 2006; Serrano eta Vázquez, 2007; Van Dijk et al., 2007). New Yorkeko dorre bikietako 2001eko atentatuaren ostean, atxilotze-zentroen irekiera eta giza eskubideen urratzeak sistematikoak izan dira, Huntungtonek (1996) abiarazitako zibilizazioen talkaren diskurtsoak eta Gaizkiaren Ardatzaren artikulazioak bultzatuta. Era berean, Iraken esku-hartze militarra egin zen, hiritarren gehiengoak isilik zirauen bitartean; eta hori guztia askatasunaren eta segurtasunaren izenean gauzatu zen (Sides eta Gross, 2011). Gainera, airezko kontrola areagotu egin zen segurtasun antiterrorista «bermatzeko» asmoz. Horrek, besteak beste, bidaiarien erregistroa (Passenger Name Record) egitea ekarri zuen, 
edota ustezko atentatuak ekiditeko polizien presentzia areagotzea (Arteaga, 2015). Europako hiri ezagunenak ere gotortu egin dira ustezko atentatuen aurrean: bisitariak kontrolatzea sistematikoa da, baita Batasunaren Eskubideagatik mugikortasun askea duten horientzat ere. Bideo-segurtasuna handitu da, eta kalea hartu dute poliziek, hesiek eta kamioi eta furgonetekin Bartzelonan eta Berlinen egindakoen moduko erasoak ekiditeko traba-objektuek ere. Hain zuzen ere, Belgikan izandako erasoaren ostean (2016ko martxoaren 22an), Holandak, Frantziak, Espainiak eta Italiak areagotu egin dituzte segurtasun-neurriak eta indartu egin dituzte mugetako kontrolak.

Gizartea segurtasun-politiketan oinarritzeak Europar Batasunera heldutako errefuxiatuekiko jarrera eta neurri zehatzak hartzea ekarri du. Barrenechearen ustez (2009), atentatuak egon daitezkeen beldurraren diskurtsoa erabiliz, errefuxiatuen eta harrera-eskaera egin dutenen eskubideak urratu egin dira. Human Rights Watch (ikusi World Report in HRW, 2016) eta antzeko elkarteek salatu dutenez, Mendebaldeko gizarteetan giza eskubideak arriskuan daude, batik bat, gobernuek «beldurraren politika» lematzat hartu dutelako atentatu terroristen eta aipatu ditugun errefuxiatuen etorreraren ostean. Nazio Batuen Giza Eskubideen Batzordeak (2008) adierazi duenez, giza eskubideak, demokrazia eta legearen inperioa atentatu terroristek kaltetuak egon daitezke. Terrorismoak europar hiritarren eskubideetan eragina duen modura, estatuek terrorismoaren kontra borrokatzeko hartutako neurriak ere giza eskubideak murrizten ari dira.

Hala ere, interbentzio militarrak edo herritarren eskubideak konprometitzen dituzten neurri hauek legitimatuak izatea lortzen dute kriminologian delituari beldurra izenez ezagutzen den kontzeptuaren bitartez (Vozmediano, San Juan eta Vergara, 2008; Vozmediano, 2010). Delituari beldur hori zigor-neurriekin eta segurtasunaren diskurtsoan adostasun gehiagorekin lotzen da eta bakeari sostenguan eta giza eskubideen nagusitasunean adostasun gutxiagorekin (Arian, 1989; Gordon eta Arian, 2001; Maoz eta McCauley, 2005; Crowson, 2007).

Delituari beldurra eraikitzeko prozesu honetan, mehatxua irudikatzen duen taldearen identifikazioa elementu garrantzitsu bat da. Fokua aurkari nabarmenaren gainean jartzen denean, beldurraren areagotzea jasangarriagoa bihurtzen da (Bauman, 2017). Kanpoko etsaiaren identifikazio eta definizio hau gure giza ondasunen gainean egingo da, endotaldearen beharrei edo baldintzei arreta jarriz (Tajfel, 1978; Tajfel eta Turner, 1979).

Mendeetan zehar, hainbat europar herrialde eta nazio beren identitate bereizien aldarrikapenean egon dira. Horregatik, Maastrichteko Tratatua sinatu zenetik, europar herritarren artean identifikazioa eta kohesioa sortzen duen europar identitate bat eraikitzean oso larriturik egon dira europar erakundeak. Erronka horretan, Mendebaldeko zibilizazioan sakonki finkatutako europar etnozentrismoak oinarrizko papera jokatu du bere buruaren perspektiba bat elikatzen, non Europak nagusitasun moralaren, zibilizazioaren eta giza eskubideen jabetza eskuratu duen eta, besteei, bere mugetatik kanpo gelditzen direnei (eta aliatuak ez diren horiei guztiei), barbaroen edo basatien etiketa ipini (Quijano, 2000; Febvre, 2001). 
Hala ere, nahiz eta Europa dibertsitate kulturalarekin eta giza balioekin erlazionatu, aztertutako ikerketek ezagutzera ematen dute lotura sendoa dagoela identifikazio europarraren eta jarrera xenofoboen artean. Adibidez, Licata eta Kleinek (2002) planteatu zuten Maastrichteko hitzarmenetik aurrera exotaldearekiko diskriminazioa legitimatzen duen herritartasun europar bat existitzen zela, eskubide batzuk esklusiboki populazio europarrari esleitzen dizkiotelako. Uste horiek indartu ziren, europar bezala gehiago identifikatzen ziren pertsonak neurri txikiago batean identifikatzen zirenak baino xenofoboagoak zirela ikustean. Ondorengo ikerketa batean aurkitu zen ezen tolerantziarekin lotutako balioak zituen Europa batean egotearen desioak besteekiko kontrako jarreren adierazpen publikoa ezkutatzen zuela, nahiz eta, jarrera xenofoboak audientzia pribatu baten aurrean ezkutatuak ez izan (Klein et al., 2003).

Zentzu berean, Ullrich, Christ eta Schületer-ek (2006) egindako ikerketan aurkitu zuten europar identifikazio altua zuten pertsonak sentiberagoak zirela kanpokoa den eta mehatxagarri bezala hautematen den talde baten aurrean. Mehatxuaren pertzepzio horrek bi ikerketa desberdinetan exotaldearekiko aurreiritzi-maila igo zuen.

Izan ere, europarren artean gutxiengo etnikorik gabeko auzoetan bizitzearen aldeko lehentasuna aurkitu da; hau da, europarren bizilagun perfektuak gutxiengo etnikoetako kiderik gabeko auzoetan bizitzen zirela (Semyonov, Glikman eta Krysanek, 2007). Sekerdej eta Kossowska-k (2011) ondoren egindako ikerketetan, nazionalismoak mehatxu-pertzepzio handiagoa aurresaten zuela ikusi zen, baita politika antiterroristekin egindako akordioa ere, nahiz eta azken horiek eskubide zibilen murrizketa eragin. Nabaritutako mehatxua bitartekari moduan jokatzen zuen aldagai bezala aurkitu zen nazionalismoaren eta inplementatutako politiken akordioaren artean. Aurkikuntza horiek, talde arteko gertaerak identifikazio sozialean eragindako erantzun emozionalak sortzen dituen ikuspegi batean oinarritzen dira (Giner-Sorolla eta Maitner, 2013). Horrela, mehatxuaren sentsazioa talde arteko elkarrekintzetan nabaritzen da eta emozio horien talde-bizipenek ondorengo erreakzio-politiketan eragin handia izan dezakete (Porat, Halperin eta Tamir, 2016).

Hala ere, nahiz eta orain arte ikerketa gehienak talde arteko testuingururako mehatxuaren ondorio negatiboen informazioa biltzeaz arduratu, duela gutxi haren potentzial positiboa aztertzen hasi dira ere. Hau da, erantzun antisozialak sortzeaz gain, gaur egun bizitzen ari garen krisi humanitarioek erantzun prosozialak sortzeko duten indarra ere ikertzen hasi dira (Carlo et al., 2013). Babesaren krisi humanitarioaren aurrean instituzioek emandako erantzuna desegokia izan daitekeen arren, gizarte zibilaren ongietorria eta giza eskubideen aldeko aldarrikapena azaldu duten askotariko ekintzak gauzatu dira (arropa-, diru-, janari-bilketa, mobilizazio kolektiboak, errefuxiatuen esparruetara bidaiak, etab.). Dudarik gabe, gizarte zibilak bakearen kulturarekiko elkartasun eta konpromisoa erakutsi du.

Mehatxua eta beldurra susta daitekeen modu berean, bakerako hezkuntza, altruismoaren hedapena, emozio moralak eta balio prosozialak oso tresna baliagarriak izan daitezke azaleratzen diren diskurtso arrazista eta xenofoboei aurre 
egiteko. Horiek bezalako fenomenoen aurrean sortzen diren erlazio emozionalen kudeaketek eragina izan dezakete gizartean aurrera eramango diren politikekiko jarreretan. Zehazki, harrera eta integrazioa bezalako neurri prosozialekin egindako akordioa talde-kulpa eta talde-lotsa bezalako emozioek lagundu dezakete. Berezko taldeak arau moral bat hautsi duela pentsatzen denean, kulpa sentitzen dela ikusi da, eta urratutako arau hori konpontzeko joerarekin lotzen da (Páez, Espinosa eta Bobowik, 2013). Bidegabeko ekintza bat egin dutenekin identifikazio erreal edo sinbolikoak lotsa emozio kolektiboa azaleratzen du (Dresler-Hawke eta Liu, 2006). Lotsa ezkutatzeko saiakerekin lotzen da (Tangney, Stuewig eta Mashek, 2007), baina bidegabeko ekintza bat berezko taldeak egiten duenean, konpontzeko saiakerekin lotu daiteke (Wicker, Payne eta Morgan, 1983). Horren harira, emozio moral hauen agerpenak eta Europarekiko identifikazio baxuak integraziorako aldeko jarrerak bultza zitzaketen, eta, integrazio-jarreren bitartez, europar identitatea ere modu positiboagoan agertu.

Horrela, arrazismoa eta xenofobia saihesteko martxan jarri diren ekintzak sinesmenak eta emozioak aldatzeko helburu horietara orienta daitezke. Taldeerritual moduan, sentsibilizazio-ekintzek funtzio morala eta normatiboa betetzeko lagundu dezakete (Rossano, 2012). Aurretik egindako ikerketek erakutsi dutenez, talde-topaketetan parte hartzeak solidaritatean oinarritutako funtsezko sinesmen sozialak indartzen ditu (De Rivera eta Páez, 2007; Rimé 2009), halaber talde arteko jarrera positiboak eta alofilia sustatzeko lagundu dezakete (Morales, 2012).

Helburu horrekin, SOS Arrazakeriak, «Ongi Etorri errefuxiatuak» erakusketa ipini zuen Gipuzkoa eta Arabako UPV/EHUko campusetan Ikasleen, Enplegu eta Gizarte Erantzukizuneko Errektoreordetzaren babesarekin. Bertan, ikasle unibertsitarioek informazioa jaso zuten gaiaren inguruan 17 panelez osatutako erakusketaren bisita gidatu batean, egungo krisiaren kausen inguruan. Besteak beste, historian izandako desplazamenduen inguruan gehiago ikasi zuten; errefuxiatuen eta etorkinen arteko dikotomiaren inguruan aritu ziren; Euskal Herriko, Espainiako Estatuko eta Europako historiaren inguruan mintzatu ziren; Europako politika ofizialak dituen dilemaren inguruan jardun ziren; beste politika batzuen garapena aldarrikatu duten ahots kritikoen inguruan hitz egin zuten; eta aurreiritzien errefusa eta konpromiso pertsonalaren aldarriaren inguruan eztabaidatu zuten. Esku-hartze horren bidez, pertsona errefuxiatuekiko eta haien egoerarekiko jarrera eta emozioetan eragitea nahi izan zen. Horretarako, honako balio hauek bultzatu ziren: emozio moralak sustatu, mehatxu-sentsazioa gutxitu, mugak ixteko politikak ukatzeko neurriak handitu eta harrera- eta integrazio-neurriekin koherenteak diren balio prosozialak sustatu. 


\section{Helburuak}

Ikerketa honek identifikatu nahi ditu ikasle unibertsitarioen emozio eta jarrerak populazio errefuxiatuaren etorreraren aurrean, mehatxuen pertzepzioa, ezarri beharreko politikekiko jarrerak (mugen itxiera versus gizarteratzea) eta kolektibo horrekiko laguntzazko balio prosozialen presentzia edo hutsunea. Halaber, emozio eta jarrera horietan identitate europarrak duen papera aztertu nahi izan da. Baita ikasleekin egindako sentsibilizazio-ekintza bat ebaluatzea ere, jarreretan, emozioetan, mehatxuaren hautematean, ezarri beharreko politikekiko jarreretan eta balio prosozialen gehiagotzean izandako eragina.

\section{Metodologia}

\subsection{Parte-hartzaileak eta prozedura}

Guztira 156 ikaslek parte hartu zuten, gehienak $(\% 74,4)$ emakumezkoak izan ziren, eta $20,36 \mathrm{ko}$ batez besteko adina zuten $(D T=3,15)$. Denak Euskal Herriko Unibertsitateko Psikologiako (\% 53,2), Kriminologiako (\% 36,6) eta Zuzenbideko $(\%$ 10,2) ikasleak izan ziren. Parte-hartzaileek SOS Arrazakeria Gipuzkoak egindako sentsibilizazio-ekintzan («Ongi Etorri Errefuxiatuak» erakusketa inguruko bisita gidatua) parte hartu zuten. Bisita horien helburua, hasteko, errefuxiatuen errealitateari buruzko ezagutza zabaltzea izan zen, hau da, haien egoera, beharrak eta Europa, estatu eta eskualde mailako administrazioen erantzuna krisi humanitarioaren kudeaketari eta errefuxiatuen harrerari dagokienez. Ondoren, emozio moralak eta balio prosozialak sustatzea eta errefuxiatuen eta aterpe-eskatzaileen aurkako talde arteko etsaitasuna murriztuko duen kontzientzia bat sustatzea. Bukatzeko, errefuxiatuen etorrerak ekarriko dituen aurreiritzi saihetsezinei eta arrazakeria eta xenofobia hazten dituen humusari aurre egin ahal izateko, elkartasun- eta justizia-balioak sendotzea. Bisitetan parte hartu ondoren, ikasleek hautemandako mehatxuaren sentsazioa gutxitzea espero zen eta, emozio moralak, berriz, handitzea. Gainera, mugen itxierei zuzendutako neurrien aurrean ukatze handiago bat nabaritzea espero zen, baina harrera- eta integrazio-neurrien aurrean, aldiz, adostasun handiagoa azaltzea, hau da, parte-hartzaileen prosoziabilitatea handituz.

Ikasleek esku-hartzean parte hartu baino aste bat lehenago lehenengo galdetegia (pre) bete zuten eta ekintzaren ondoren ezaugarri berdinak zituen bigarren galdetegi bat (post) bete zuten. 


\subsection{Datu-bilketako tresnak eta galde-sortak}

Partaideek errefuxiatuen aurrean dituzten jarrera eta emozioak neurtzeko galdetegi bat erabili zen, honako itemak eta erantzuteko aukerak erabiliz.

Errefuxiatuekiko emozioak: ad hoc galdetegi bat egin zen, Likert moduko 6 item proposatu dira. Horietako 4 (mirespena; pena; begikotasuna; gorrotoa) populazioak errefuxiatuekiko zer emozio sentitzen zuen aztertzeko erabiliak dira (Fiske et al., 2002; Cuddy, Fiske eta Glick, 2008). Bestalde, beste 2 itemek (kulpa; lotsa) errefuxiatuek bizitzen duten egoerarekiko agertzen diren emozio moralak neurtzen dituzte ( $1=$ Batere ez; $7=$ Guztiz).

Mehatxuen hautematea: kolektibo hauen aurrean populazioak zer mehatxu eduki ditzakeen aztertzeko 7 item jarri ziren (errefuxiatuen etorrerak Europan lortutako laikotasuna arriskuan jartzen du; gure ongizate sozialean ondorioak izan ditzake; errefuxiatuek berdintasun-balioak arriskuan jartzen dituzte; Europa bere kultura eta balioak galtzeko arriskuan dago; haien erlijioa Europan inposatu nahi izateak beldurtzen nau; errefuxiatuek genero-berdintasuna arriskuan jartzen dute; gure osasun-zerbitzua kolapsa daiteke; atentatu terroristen arriskua gehitzen da). Fidagarritasuna ona izan zen, alpha ,88 (pre) eta ,87 (post) ( $1=$ Guztiz desados; $7=$ Guztiz ados) (ikus Stephan eta Stephan, 2000).

Ezarri beharreko politikekiko jarrerak: errefuxiatuen egoeraren aurrean hartu behar diren neurrien adostasun-maila aztertzeko bi neurri ad hoc erabili ziren: a) Gizarteratze politikekin/neurriekin zuten adostasun-maila ikusteko 4 item erabili ziren (Errefuxiatuei harrera egiteko integrazioaren aldeko politikak sustatzea; osasun-laguntza unibertsala errefuxiatuei ematea; iristen diren errefuxiatuei laguntza sozialak eskaintzea; Europan bizi ahal izateko etxebizitza bat ematea). Fidagarritasuna ona izan zen, alpha ,84 (pre) eta ,87 (post) ( $1=$ Guztiz desados; $7=$ Guztiz ados); b) Mugen itxierarekin duten adostasun-maila neurtu zen beste 4 itemen bidez (babes-eskubidea mugatzea; errefuxiatu musulmanei sarrera mugatzea; europar mugak itxi/indartzea; Europako kontrola eta segurtasuna gehitzea). Fidagarritasuna ona izan zen, alpha ,73 (pre) eta ,67 (post) (1= Guztiz desados; $7=$ Guztiz ados).

Balio prosozialak: Likert moduko 4 item ad hoc sartu ziren populazioa zer balio prosozial egiteko prest egongo litzatekeen aztertzeko (nire etxean familia errefuxiatu bat jasotzea; errefuxiatuen alde manifestatzea; errefuxiatuak laguntzeko irabazi-asmorik gabeko elkartearekin parte hartzea; borondatezko lankide moduan errefuxiatu-esparru batera joatea). Fidagarritasuna ona izan zen, alpha ,77 (pre) eta ,79 (post) (1= Oso uzkurtua; $7=$ Oso prest).

Europar identifikazioa: Likert moduko 3 itemez osatutako eskala pasa zen, europar identifikazioaren graduaren inguruko galderak zituena (europarra sentitzen naiz; europarra izatea nire identitatearen zati garrantzitsu bat da; europarra izateaz harro nago). Fidagarritasuna ona izan zen, alpha ,87 (pre) eta ,88 (post) (1= Batere ez; 7= Guztiz) (ikus Leach et al., 2008). T-testaren analisia Europarekiko identifikazio-mailaren arabera egin ahal izateko, europar intentsitate 
deituriko bi muturreko aldagaia sortu dugu: europar intentsitate altua (media teorikoaren gainetik izandako puntuazioak) vs europar intentsitate baxua (media teorikoaren azpitik izandakoak).

Aldagai soziodemografikoak: sexua, adina eta ideologia politikoa, Likert moduko itemarekin (1= Ezker muturra; $7=$ Eskuin muturra).

\section{Emaitzak}

\subsection{Babesa bilatzen duten pertsonen aurrean hautemandako emozioak eta mehatxuak}

Babesa bilatzen duten pertsonek pena-, mirespen- eta begikotasun-maila altuak eta gorroto-emozio baxuak sortzen dituzte parte-hartzaileen artean. Gainera, pertsona errefuxiatuak aurkitzen diren egoera hautemateak kulpa eta lotsa bezalako emozio moralen maila erdi altuak pizten ditu. Parte-hartzaileen identifikazio europarrari dagokionez, erdi-mailako puntuazioak aurkitu ziren, identifikazio-maila altuak eta baxuak adierazi zituztenen arteko desberdintasuna esanguratsua izanik. Europarekin zenbat eta gutxiago identifikatu, orduan eta mirespen eta begikotasun altuagoa azaltzen zuten babesa bilatzen duten pertsonen aurrean. Europarekin oso identifikatuak sentitzen zirenek berriz, kulpa eta lotsa bezalako emozio moral baxuagoak sentitzen zituzten errefuxiatuak pairatzen ari diren egoeraren aurrean. Ez penak, ezta gorrotoak ere, ez zuten desberdintasun esanguratsurik azaldu identifikazio europarraren mailaren arabera (1. taula).

Oro har, ikasleek adierazi zuten populazio horren etorreraren aurrean mehatxuren hautemate baxua sentitzen zutela, nahiz eta osasun-zerbitzua kolapsatzearen beldurraren aurrean puntuazio altuagoak agertu. Hala ere, parte-hartzaileen identifikazio europarrak desberdintasun esanguratsuak azaldu zituen taldeen artean. Identifikazio europarra zenbat eta handiagoa izan, orduan eta mehatxuaren hautemate altuagoa azaltzen dute, balio europarrak, Europak konkistatutako laizismoa, berdintasun-balioak eta genero-ekitatea, osasun eta babes sozialen sistema arriskuan jartzearen aurrean, baita delitu terroristen aurrean ere, besteak beste (1. taula).

\subsection{Mugen itxiera, gizarteratze-politikei buruzko jarrerak eta balio prosozialak}

Gaur egungo krisi humanitarioaren kudeaketari dagozkion jarrerei loturik, gizarteratze-neurriekin adostasun altua erakutsi zuten parte-hartzaileek (populazio errefuxiatua gizarteratzeko politiken promozioa, osasun-laguntza unibertsala, laguntza sozialen erraztasuna eta harrerako etxebizitzak) eta, orokorrean, europar gizarteen sekurizazioan oinarritutako politikekin eta mugen itxierarekin desadostasuna azaldu zuten (babes-eskubidea mugatzea, populazio musulmanari sarrera mugatzea, mugetako kontrolak indartzea edota segurtasun- eta zaintzaneurriak txertatzea gizarte europarretan). Bestalde, europar identifikazioaren arabera, identifikazio altuagoa zutenek adostasun-maila altuagoa azaldu zuten sekurizazioan eta mugen itxieran oinarritutako neurriekiko. Bestalde, ordea, 


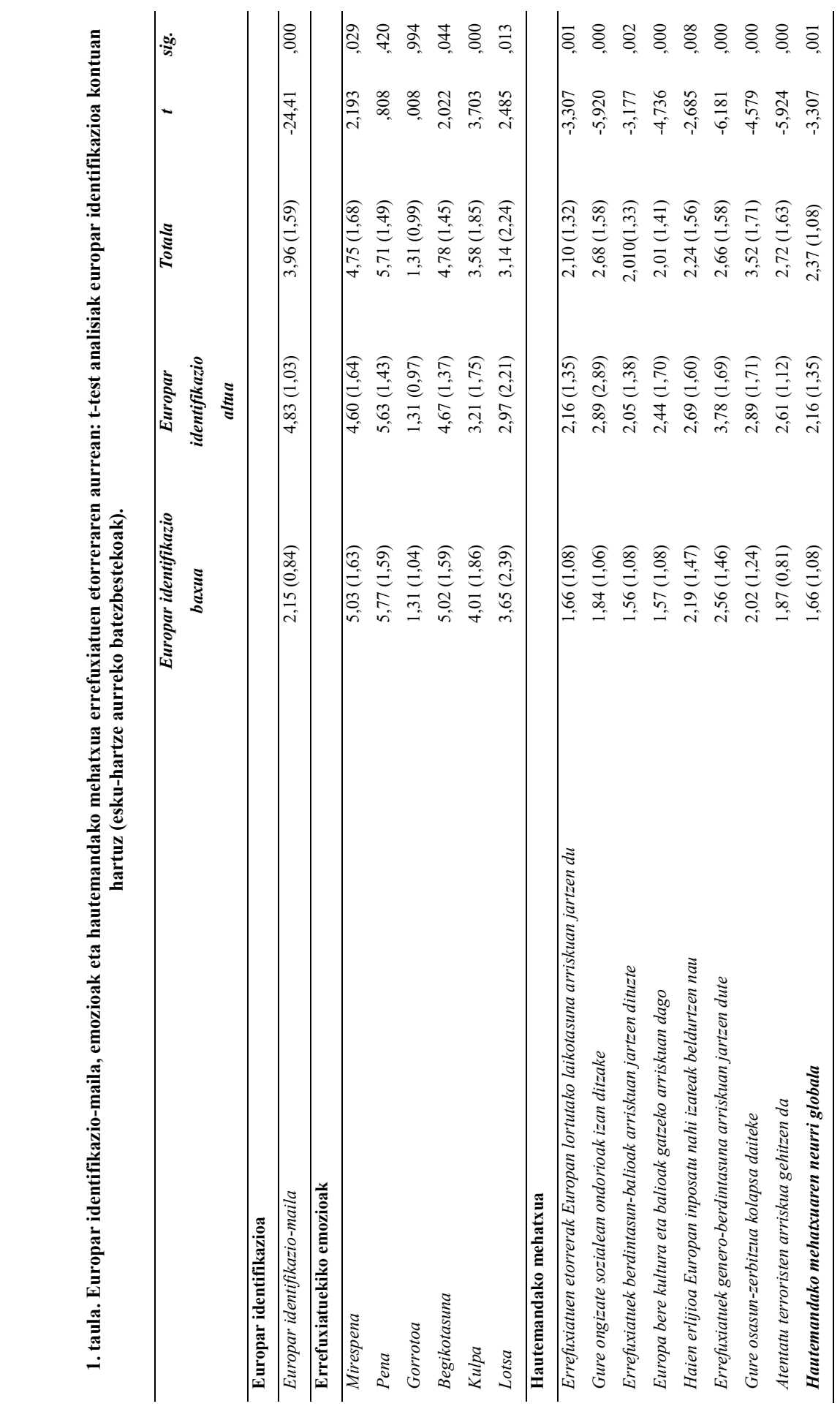


Europarekiko identifikazio baxuagoa zutenek gizarteratze-neurriekiko adostasunmaila altuagoa aurkeztu zuten (ikus 2. taula).

Jarrera prosozialei dagokienez, parte-hartzaileen babes-maila altua ikus daiteke pertsona errefuxiatuen eskubideen laguntza- eta defentsa-neurriekiko, laguntzeko helburuarekin erakunde desberdinekin bat eginez, manifestazioetan parte hartuz eta pertsona errefuxiatuak dauden eremuak bisitatuz. Neurri txikiago batean azaldu arren, errefuxiatu bat etxean hartzeko gogo handia ere erakusten dute. Taldeen arteko desberdintasunak aztertuz, jarrera prosozialen presentzia handiagoa da parte-hartzaileek Europarekin duten identifikazioa txikiagoa denean (ikus 2. taula).

\subsection{Esku-hartzea eta aldaketa populazio errefuxiatuekiko eta erlazionatutako politikekiko emozio eta jarreretan}

Azkenik, SOS Arrazakeriak ikasleekin egindako esku-hartzearen ostean, erlazionatutako laginentzat $t$-student probak egin ziren errefuxiatuekiko edukitako zenbait emozio, jarrera eta krisi humanitarioren kudeaketa zein neurritan alda daitekeen ikusteko helburuarekin. Emaitzek adierazten dutenez, sentsibilizazioekintzaren ondoren, ikasleen europar identifikazioa gutxitu egin zen. Bestalde, emozioei dagokienez, pertsona errefuxiatuekiko mirespenak eta begikotasunak esanguratsuki gora egin zuten. Emozio negatiboen artean, berriz, pena gutxitu egin zen eta kulpa eta lotsa bezalako emozio moralak, aldiz, handitu ziren. Gainera, analisiek adierazten dute mehatxuaren pertzepzioa adierazle guztietan gutxitu egin zela esku-hartzearen ostean (3. taula). Gauza bera gertatu zen mugen kontrolean oinarritutako akordioarekin, non, esku-hartzearen ostean neurri horiekin adostasun gutxiago detektatu zen. Nahiz eta, gizarteratze-politiken neurri globala esanguratsuki ez aldatu, aldaketa partzial bat egon zen adierazle batzuetan: eskuhartzeak laguntza sozial eta etxebizitza gehiago eskaintzeko akordioa handitzea lortu zuen babes-eskatzaileen artean (4. taula). Azkenik, datuek adierazten dute esku-hartzeak ikasleen balio altruistak eta prosozialak gehitzea lortu zuela.

\section{Eztabaida eta ondorioak}

Ikerketaren emaitzek zera adierazten dute: ikasleek, oro har, mirespena eta begikotasuna azaltzen dituzte populazio errefuxiatuarekiko. Aipatutako emozio positibo horiek pena- eta tristura-dosi handi batekin batera azaltzen dituzte. Kolektibo horiekiko (edota batez ere Europa babesaren krisi humanitario honen aurrean egiten ari den gestioarekiko) kulpa eta lotsa bezalako emozioak, berriz, neurri apalago batean adierazten dituzte, eta adieraztekotan, Europarekin identifikazio txikiagoa dutenek neurri handiagoan adierazten dituzte emozio horiek. Eskuin muturreko alderdi politiko desberdinetan artikulatzen doazen eta Europan zehar geroz eta islamofoboak bilakatzen ari diren jarrera anti-immigranteak kontrastatuz (Strabac eta Listhaug, 2008; Meer eta Modood, 2009), ikasleek ez dute gorrotorik ezta mehatxurik ere sentitzen kolektibo horren etorreraren aurrean. Terrorismo internazionalarekin eta errefuxiatuen etorrerarekin lotzen diren beldur-diskurtsoek ez dute eragin esanguratsurik eduki ikasleengan, eta ikasle gehienek mugak ixtearen eta Europaren sekurizazioaren aurrean desadostasuna adierazten dute. 


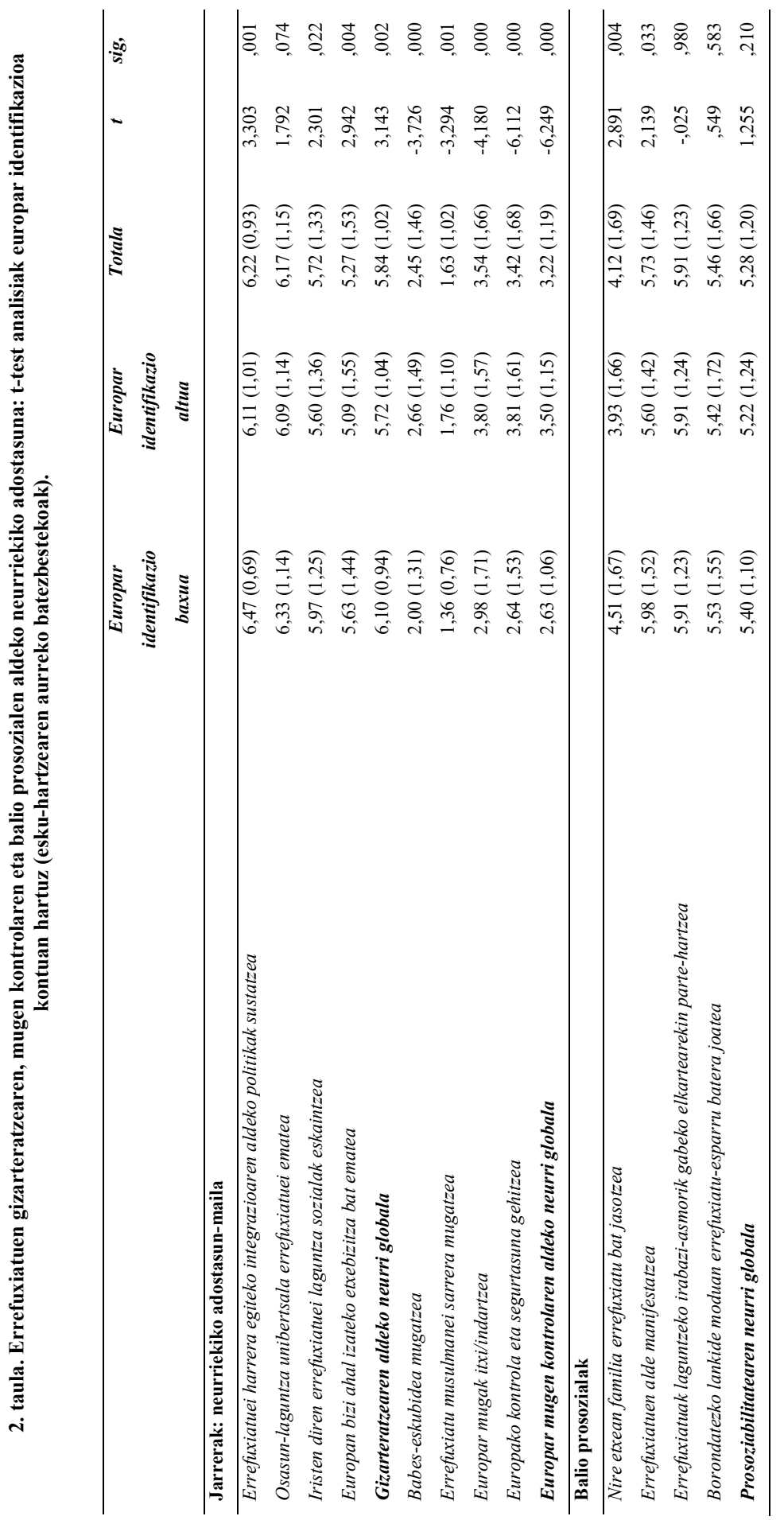




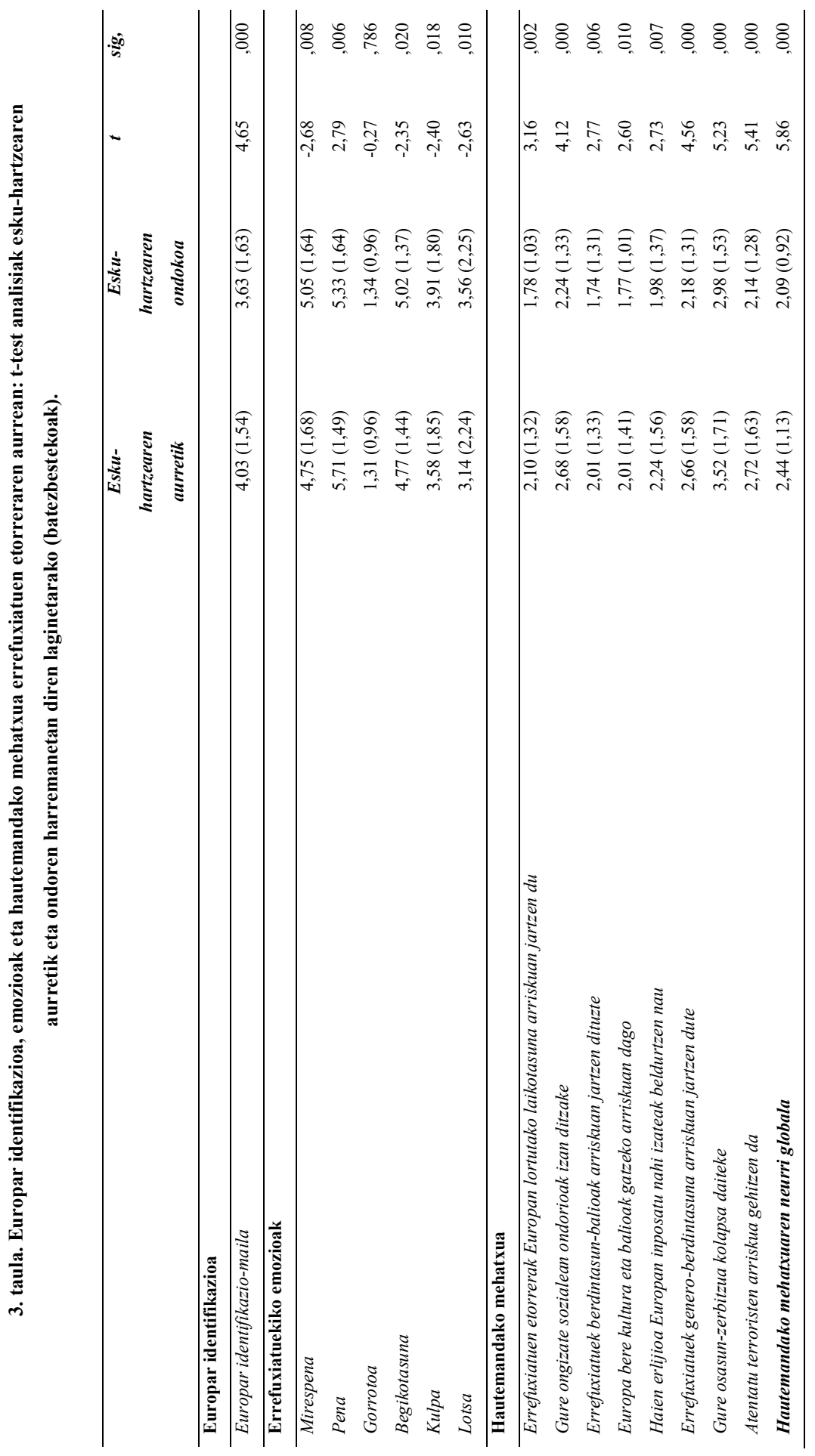




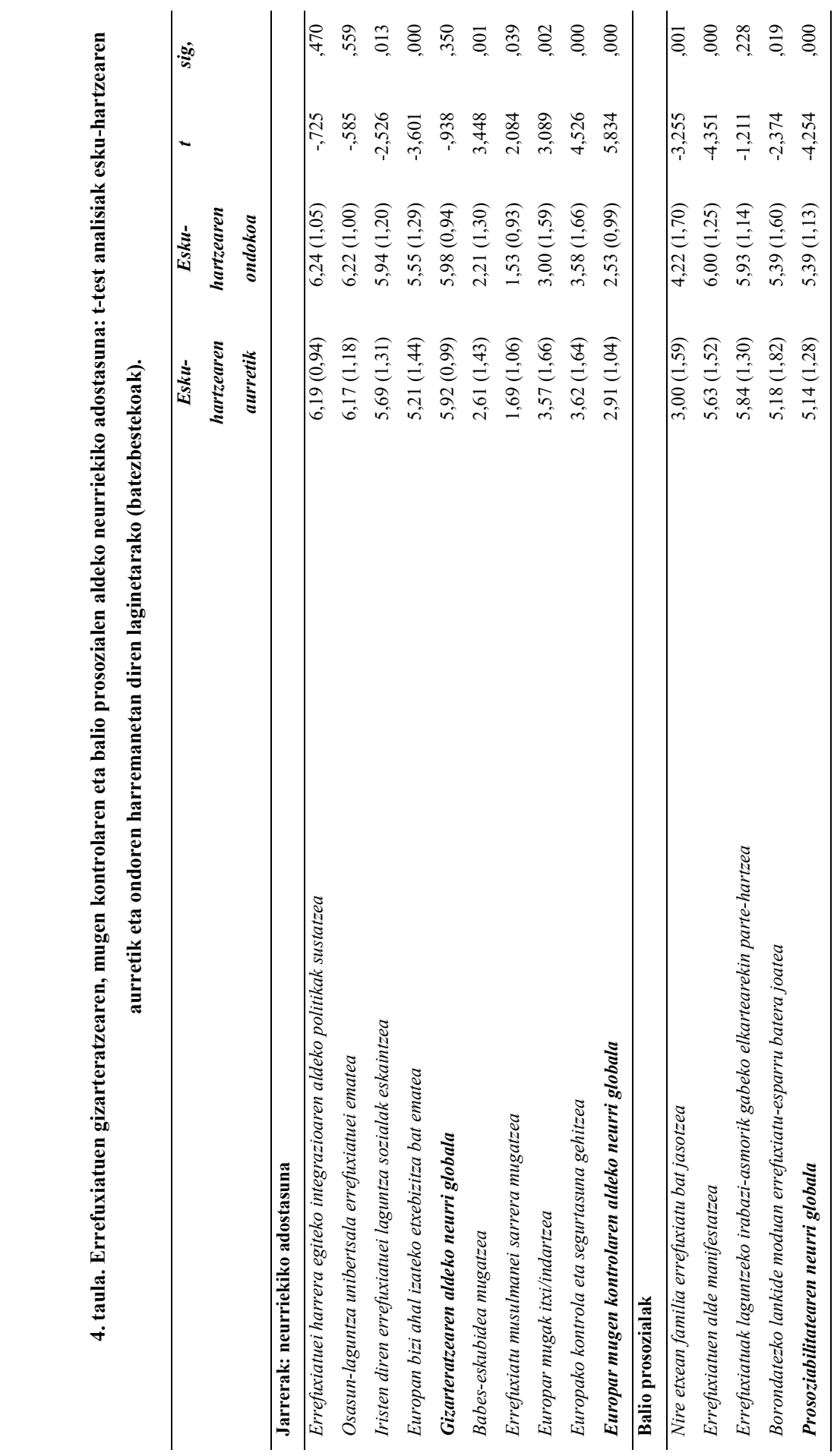


Agertzekotan, Europarekin identifikazio altua dutenen artean agertzen dira horrelako jarrerak, kontrara, kolektibo horri etxebizitzarako laguntzak, osasun-eskubideak eta prestazio-eskubideak emango dizkieten integrazio-politikak sustatzearen alde egiten dute ikasle gehienek. Halaber, ikasleen artean jarrera altruistak eta prosozialak nabarmentzen dira, eta horrek diskurtso sozialetan hainbeste zabaldu diren aipatutako jarrera hauek faltan dituen generazioaren ideiarekin kontrastatzen du. Beraz, ikerketak arrazoi nahikoak eskaintzen dizkigu baieztatzeko ikasleria solidario bat daukagula populazio errefuxiatua babesteko, haien alde mobilizatzeko, antolatzeko eta haien laguntza eskaintzeko errefuxiatuen esparruetara joateko.

Zenbait ikerketak aditzera ematen duten bezala (Breakwell eta Lyon, 1996; Licata eta Klein, 2002; Klein et al., 2003; Semyonov et al., 2007), identifikazio europarra balio humanistekin eta bateratzearen alde egiten duen populazioarekin erlazionatu ordez, errefuxiatuekiko zigor-jarrerekin erlazionatzen da. Horrela, ikerketa honetan ikusi dugun bezala, identifikazio endogrupalak bizilagun berrienganako emozio positiboak desaktibatu egiten ditu eta adierazle desberdinetan mehatxu sinboliko eta erreala indartzen du. Seguruenik, hautemandako mehatxu horren igoerak bitartekari-lana egiten du europeismoaren eta mugen itxieraren akordio handiago baten artean (Barnes, Brown eta Osterman, 2012), baita gizarteratze-politikak adosteko posibilitatea murriztearekin ere. Horrela, nazionalismo edo erregionalismo hau bake-kulturarekin erlazionatutako identitateak sustatu ordez, talde arteko gatazka goraipatzen duten identitateak potentziatzen egongo litzateke (Licata eta Klein, 2002; Klein et al., 2003; Ullrich, Christ eta Schuleter, 2006; Semyonov et al., 2007; Sekerdej eta Kossowska, 2011).

Gainera, ikerketak baieztatzen du aniztasunaren eta bakearen kulturaren sustapenarekin lotutako tresnen bidez («Ongi Etorri Errefuxituak» erakusketa hain zuzen ere), bizilagun berrien etorreraren aurrean jarrera desberdinak sor daitezkeela. Ondorioz, ikerketa honen emaitzek zera nabarmentzen dute: populazio errefuxiatuaren egoera ezagutzera, egoera horren kausen inguruan hausnartzera eta fenomeno horren aurrean administrazio publikoaren gestioa azaltzera zuzendutako sentsibilizazio-ekintzek talde arteko emozio eta jarrerak modu positiboan alda ditzaketela. Emaitzetan ikusten den bezala, ikasleek bisita gidatuetan parte hartu ondoren errefuxiatuekiko dituzten emozioak eta jarrerak positiboki aldatzen dira.

Nabarmentzekoa da esku-hartzeak pena emozioa kulpa eta lotsa bezalako emozio moralengatik aldatzen duela. Emaitza hauek sentsibilizazio-ekintzek funtzio moral eta normatiboa bete dezaketen sinesmenak indartzen dituzte (Rossano, 2012), solidaritatea indartuz (De Rivera eta Páez, 2007; Rimé, 2009), baita talde arteko jarrera positiboak ere (Morales, 2012). Azpimarratu beharra dago, emozio moral hauek ez daudela pertsona errefuxiatuei zuzenduak, Europak egindako ekintza negatiboei baizik (Doosje et al., 1998; Smith et al., 2002; Branscombe, Slugoski eta Kappen, 2004). Ondorioz, Europarekin identifikazio baxu bat izatea eta gaur egungo krisi humanitarioaren gestio desegoki bat egitea, emozio hauen oinarrian egon daitezke. Emozio horien adierazpenek (pena, lotsa eta kulpa) azal dezakete nola konpondu egoera integrazio-politiken edo balioen hedapenaren sustapenaren bidez. 
Horrela, honakoa ondoriozta dezakegu: interbentzioak emozioak areagotu ditzake, termino negatiboetan eragiten duen erregionalismo europarra eta mugen itxiarekiko jarrerak desaktibatzea lortzen duelako eta balio prosozialak eta integrazioaren aldeko neurriekiko adostasuna indartzen laguntzen duelako. Beraz, sentsibilizaziokanpaina honen bidez, esanahi berriak eraiki eta sinesmenak zentzu positiboan aldatu direla esan dezakegu. Hori dela-eta, etorkizunera begira garrantzitsua dirudi jarrera-aldaketetara eta emozioen eta bake-kulturaren eta europar balioen aldeko giza eskubideekin bateragarri diren identitateak eraikitzera zuzendutako ekintzak sustatzen jarraitzea. Europaren identitate-eraikuntzaren prozesuan erronka bat izan daiteke balioen aldeko eta inplementatutako neurrien artean koherentzia bat lortzea. Horrela, errazagoa izango da Europa identifikatzea balioen sustatzaile gisa eta ez eskubideen urratzaile gisa.

Dena den, ikerketa hau aurretik talde arteko jarrera positiboak zituzten ikasleen laginarekin egin da. Beraz, beharrezkoa izango litzateke honelako ikerketak biztanleria arruntarekin egitea, errefuxiatuekiko jarrerak aldakortasun handiagoa duelako eta esku-hartze honetan ezarritako emaitzak konfirmatzen diren ezagutzeko.

\section{Erreferentziak}

Altheide, D.L. (2006): «Terrorism and the Politics of Fear», Cultural Studies, Critical Methodologies, 6, 415-439, <https://doi.org/10.2307/j.ctt183p6n7.9>.

Arian, A. (1989): «A people apart: Coping with national security in problems in Israel», Journal of Conflict Resolution, 34(4), 605-631, < https://doi.org/10.1177/0022002 789033004002>.

Arteaga, F. (2015): «La lucha contra el terrorismo yihadista en la UE», Afcar ideas, 45, 2729 .

Barnes, C.D.; Brown, R.P. eta Osterman, L.L. (2012): «Don't tread on me: Masculine honor ideology in the US and militant responses to terrorism», Personality and Social Psychology Bulletin, 38(8), 1.018-1.029, <https://doi. org/10.1177/0146167212443383>.

Barrenechea, L. (2009): El respeto a los derechos humanos en la lucha contra el terrorismo en España, <http://fride.org/descarga/COM_Derechos_Humanos_terrorismo2_ ESP_feb09.pdf> helbidean eskuratua.

Bauman, Z. (2017): Extraños llamando a la puerta, Paidós, Bartzelona.

Biernat, M. eta Dovidio, J.F. (2000): «Stigma and stereotypes», in T.F. Heatherton, R.E. Kleck, M.R. Hebl, \& J.G. Hull (ed.), The social psychology of stigma, Guilford Press, New York, 88-125

Bilsky, L. (2009): «Muslim headscarves in France and army uniforms in Israel: a comparative study of citizenship as mask», Patterns of Prejudice, 43(3-4), 287311, <https://doi.org/10.1080/00313220903109193>.

Branscombe, N.; Slugoski, B. eta Kappen, D.M. (2004): «The measurement of collective guilt. What it is and what it is not», in N. Branscombe eta B. Doosje (ed.), Collective guilt. International perspectives, Cambridge University Press, New York, 16-34.

Breakwell, G.M. eta Lyons, E. (1996): Changing European Identities: Social Psychological Analyses of Change, International Series in Social Psychology, ButterworthHeinemann, Oxford. 
Carlo, G. et al. (2013): «The structure and correlates of a measure of prosocial moral reasoning in adolescents from Spain», European Journal of Developmental Psychology, 10(2), 174-189, <https://doi.org/10.1080/17405629.2012.762909>.

CEAR (2016): Las personas refugiadas en España y Europa, <https://www.cear.es/wpcontent/uploads/2016/06/Informe_CEAR_2016.pdf> helbidean eskuratua. (2017): Las personas refugiadas en España y Europa, <https://www.cear.es/wpcontent/uploads/2017/06/Informe-Anual-CEAR-2017.pdf> helbidean eskuratua.

Conejero, S. et al. (2004): «Alteración afectiva personal, atmósfera emocional y clima emocional tras los atentados del 11 de marzo», Ansiedad y Estrés, 10(2-3), 299-312.

Crowson, H.M. (2007): «Authoritarianism, perceived threat, and human rights attitudes in US law students: A brief look», Individual Differences Research, 5, 260-266.

Cuddy, A.J.C.; Fiske, S.T. eta Glick, P. (2007): «The BIAS Map: Behaviors from intergroup affect and stereotypes», Journal of Personality and Social Psychology, 92, 631648.

- eta —, (2008): «Competence and warmth as universal trait dimensions of interpersonal and intergroup perception: The stereotype content model and the BIAS map», in M.P. Zanna (ed.), Advances in experimental social psychology, 40, Academic Press, New York, 61-149.

De Rivera, J. (1992): «Emotional climate: social structure and emotional dynamics», International Review of Studies on Emotion, 2, 197-218.

De Rivera, J. eta Páez, D. (2007): «Emotional climate, human security and cultures of peace», Journal of Social Issues, 63(2), 233-253.

Doosje, B. et al. (1998): "Guilt by Association: When one's group has a negative history», Journal of Personality and Social Psychology, 75, 872-886.

Dresler-Hawke, E. eta Liu, J.H. (2006): «Collective shame and the positioning of German national identity», Psicología Política, 32, 131-153.

Elchardus, M. eta Spruyt, B. (2014): «Universalism and anti-Muslim sentiment», International Journal of Intercultural Relations, 38(1), 75-85, <https://doi. org/10.1016/j.ijintrel.2013.03.001>.

Febvre, L. (2001): Europa. Génesis de una civilización, Crítica, Bartzelona.

Fiske, S.T. et al. (2002): «A model of (often mixed) stereotype content: Competence and warmth respectively follow from perceived status and competition», Journal of Personality and Social Psychology, 82, 878-902.

Giner-Sorolla, R. eta Maitner, A.T. (2013): «Angry at the unjust, scared of the powerful: emotional responses to terrorist threat», Personality \& Social Psychology Bulletin, 39, 1.069-1.082.

Gordon, C. eta Arian, A. (2001): «Threat and decision making», Journal of Conflict Resolution, 45(2), 196-215.

Human Right Watch (2016): «Politics of Fear» Threatens Rights Terror Attacks, Refugee Crisis, and Broad Global Crackdown, HRW, Estatu Batuak, <https://www.hrw. org/sites/default/files/world_report_download/wr2016_web.pdf> (Kontsulta: 201710-04).

Huntungton, S. (1996): The Clash of Civilizations and the Remaking of World Orde, Simon Schuster, New York.

Klein, O. et al. (2003): «How European am I?: Prejudice expression and the presentation of social identity», Self and ldentity, 2(3), 251-264, <https://doi. org/10.1080/15298860309025>.

Kundnani, A. (2007): The End of Tolerance: Racism in the 21st Century, Pluto Press, Londres. 
Leach, C.W. et al. (2008): «Group-level self-definition and self-investment: a hierarchical (multicomponent) model of in-group identification», Journal of Personality and Social Psychology, 95(1), 144-165.

Licata, L. eta Klein, O. (2002): «Does European citizenship breed xenophobia? European identification as a predictor of intolerance towards immigrants», Journal of community \& applied social psychology, 12(5), 323-337, < https://doi. org/10.1002/casp.684>.

Louis, W.R. et al. (2007): «Why Do Citizens Want to Keep Refugees Out? Threats, Fairness and Hostile Norms in the Treatment of Asylum Seekers", European Journal of Social Psychology, 37(1), 53-73, <https://doi.org/10.1002/ejsp.329>.

Maoz, I. eta McCauley, C. (2005): «Psychological correlates of support for compromise: A polling study of Jewish-Israeli attitudes toward solutions to the Israeli Palestinian conflict». Political Psychology, 26(5), 791-808.

Meer, N. eta Modood, T. (2009): «The multicultural state we are in: Muslims, "multiculture" and the "civic re-balancing" of British multiculturalism", Political Studies, 57(3), 473-497, <https://doi.org/10.1111/j.1467-9248.2008.00745.x>.

Morales, J.F. (2012): Una visión positiva del liderazgo y sus fortalezas, Lección inaugural de la Real Academia de Doctores de España, UNED, Madril.

Murray, K.E. eta Marx, D.M. (2013): «Attitudes toward unauthorized immigrants, authorized immigrants, and refugees», Cultural Diversity and Ethnic Minority Psychology, 19(3), 332-341.

Páez, D.; Espinosa, A. eta Bobowik, M. (2013): «Emotional Climate: How It is shaped, fostered and changed? », in Hermans, Rimé eta Mesquita (ed.), Changing Emotions, Psychology Press, New York, 113-119.

Porat, R.; Halperin, E. eta Tamir, M. (2016): «What we want is what we get: Group-based emotional preferences and conflict resolution», Journal of Personality and Social Psychology, 110(2), 167-190.

Quijano, A. (2000): «Colonialidad del poder, eurocentrismo y América Latina», in E. Lander (ed.), La colonialidad del saber: eurocentrismo y ciencias sociales. Perspectivas latinoamericanas, CLACSO, Buenos Aires, 201-246.

Rimé, B. (2009): «Emotion elicits the social sharing of emotion: Theory and empirical review», Emotion Review, 1, 60-85.

Rossano, M.J. (2012): «The essential role of ritual in the transmission and reinforcement of social norms", Psychological Bulletin, 138, 529-549

Saroglou, V.; Corneille, O. eta Van Cappellen, P. (2009): «Speak, Lord, your servant is listening: Religious priming activates submissive thoughts and behaviors», The International Journal for the Psychology of Religion, 19, 143-154, < https://doi. org/10.1080/10508610902880063>.

Schweitzer, R. et al. (2005): «Attitudes towards refugees: The dark side of prejudice in Australia», Australian Journal of Psychology, 57(3), 170-179, <https://doi.org/10. 1080/00049530500125199>.

Sekerdej, M. eta Kossowska, M. (2011): «Znaczenie potocznych teorii grupy w dynamice relacji międzygrupowych», in W M. Kofta eta M. Bilewicz (ed.), Wobec obcych: zagrożenie psychologiczne a stosunki międzygrupowe, Wydawnictwo Naukowe PWN, Warszawa, 248-262.

Semyonov, M.; Glikman, A. eta Krysan, M. (2007): «Europeans' preference for ethnic residential homogeneity: Cross-national analysis of response to neighborhood ethnic composition», Social Problems, 54(4), 434-453, <https://doi.org/10.1525/ sp.2007.54.4.434>. 
Serrano, A. eta Vázquez, C. (2007): Tendencias de la criminalidad y percepción social de la inseguridad ciudadana en España y la Unión Europea, Edisofer, SL, Madril.

Sides, J. eta Gross, K. (2011): «Stereotypes of Muslims and Support for the War on Terror», The Journal of Politics, 75(3), 583-598, <https://doi.org/10.1017/ s0022381613000388>.

Stephan, W.G. et al. (1998): «Prejudice toward immigrants to Spain and Israel: An integrated threat theory analysis», Journal of Cross-Cultural Psychology, 29, 559-576, <https://doi.org/10.1177/0022022198294004>.

Stephan, C.W. eta Stephan, W.G. (2000): «The measurement of racial and ethnic identity», International Journal of Intercultural Relations, 24(5), 541-552.

Skitka, L.J. et al. (2006): "Confrontational and Preventative Policy Responses to Terrorism: Anger Wants a Fight and Fear wants, Them to Go Away», Basic and Applied Psychology, 28(4), 375-384.

Strabac, Z. eta Listhaug, O. (2008): «Anti-Muslim prejudice in Europe: a multilevel analysis of survey data from 30 countries», Social Science Research, 37, 268-286, <https://doi.org/10.1016/j.ssresearch.2007.02.004>.

Tajfel, H. (1978): «The psychological structure of intergroup relations», in H. Tajfel (ed.), Differentiation between social groups: Studies in the social psychology of intergroup relations, Academic Press, Londres.

Tajfel, H. eta Turner, J. (1979): "An integrative theory of intergroup conflict», in W.G. Austin eta S. Worchel (ed.), The Social Psychology of Intergroup Relations. Monterey, Brooks/Cole, Kalifornia, 33-47.

Tangney, J.P.; Stuewig, J. eta Mashek, D.J. (2007): «Moral emotions and moral behavior», Annual Review of Psychology, 58, 345-372, <https://doi.org/10.1146/annurev. psych.56.091103.070145>.

Ullrich, J.; Christ, O. eta Schlüter, E. (2006): «Merging on Mayday: Subgroup and superordinate identification as joint moderators of threat effects in the context of European Union's expansion», European Journal of Social Psychology, 36(6), 857-876.

UNHCR (2016): Global trends: Forced displacement in 2015, <http://www.unhcr. org/576408cd7.pdf> helbidean eskuratua.

Van Dijk, J.J.M. et al. (2007): The Burden of Crime in the EU. Research Report: $A$ Comparative Analysis of the European Crime and Safety Survey (EU ICS) 2005, $<$ http://www.europeansafetyobservatory.eu/euics_rp.htm> helbidean eskuratua.

Vozmediano, L. (2010): Miedo al Delito y Sostenibilidad Urbana: Análisis Ecológico, Propuestas de Medición y Trasferencia de Resultados, Gizarte Psikologia eta Portaera Zientzien Metodologia Saileko argitaratu gabeko doktore-tesia, UPV/ EHU, Donostia.

Vozmediano, L.; San Juan, C. eta Vergara, A. (2008): «Problemas de medición de miedo al delito: algunas respuestas teóricas y técnicas», Revista electrónica de Ciencia Penal y Criminología [en línea], 10, 1-15, <http://criminet.ugr.es/recpc/10/ recpc10-07.pdf> helbidean eskuratua.

Wicker, F.W.; Payne, G.C. eta Morgan, R.D. (1983): «Participant descriptions of guilt and shame», Motivation and Emotion, 7(1), 25-39. 


\section{Komunikabideetan agertutako berriak:}

Alonso, J.M. (2015eko azaroaren16a): «Censuran al obispo Munilla por vincular la oleada de refugiados con el terrorismo», El Mundo, <http://www.elmundo.es/pais-vasco/ 2015/11/16/5649cfa946163f0a4a8b45ef.html> helbidean eskuratua.

González, C. (2016ko abenduaren 20a): «La penúltima de Percival Manglano en Twitter: relaciona el atentado en Berlín con los refugiados», Tremending, <http://www. publico.es/tremending/2016/12/20/la-penultima-de-percival-manglano-en-twitterrelaciona-el-atentado-en-berlin-con-los-refugiados> helbidean eskuratua.

Saavedra, P.G. (2016ko uztailaren 11): «Merkel admite ahora que los terroristas se infiltran como refugiados», La Gaceta, <http://gaceta.es/noticias/ano-despues-losalemanes-destierran-welcome-refugees-11072016-2134> helbidean eskuratua. 

